\title{
Genetic Diversity of Some Sweet Cherry Cultivars Based on Molecular Markers
}

\author{
Ioana Virginia BERINDEAN ${ }^{1}$, Elena TĂMAȘ ${ }^{1}$, Oana Maria TODERIC ${ }^{1}$ and Ioan ZAGRAI ${ }^{2}$ \\ ${ }^{1}$ University of Agricultural Sciences and Veterinary Medicine, Agriculture Faculty, 3-5 Calea Manastur \\ St., 400372, Cluj-Napoca, Romania; \\ ${ }^{2}$ Fruit Research and Development Station Bistrița, 3 Dumitrei Nou St., 420127 Bistrita, Romania \\ *corresponding author, e-mail: oanatoderic@yahoo.com
}

Bulletin UASVM series Agriculture 73(2)/2016

Print ISSN 1843-5246; Electronic ISSN 1843-5386

DOI 10.15835/buasvmcn-agr: 12405

\begin{abstract}
Sweet cherry (Prunus avium L.), originated around the Caspian and Black Sea, is an important fruit tree species of economic interest, and hence, breeding and conservation are requested (. Genetic analysis at the molecular level can be used effectively to study molecular polymorphism existing between intraspecific and interspecific tree species and phylogenetic relationships between them and their hybrids. The purpose of this study was to characterize and determine genetic relationships among the sweet cherry native genotypes belonging to Fruit Research \& Development Station Bistrita, Romania, using RAPD markers. To eliminate the existence of possible synonyms from national romanian collection, we collect four Van cultivars, from four different national collection. For molecular analysis of the 16 varieties of sweet cherry were considered 13 RAPD primers selected from the literature. They were later used to determine the genetic variability at the molecular level using PAST program, and the dendrogram was generated based on Jaccard's genetic distance. The dendrogram constructed by PAST software. The quantity and quality of the DNA obtained was suitable to achieve PCR amplification step. Only seven out of the 13 RAPD primers have generate polymorphic bands. The rest of seven were monomorphics. The most polymorphic primer was OPB10 which generated 11 bands from which $100 \%$ were polymorphic.Seven RAPD primers generated a high level of polymorphism which allowed to divide these cherry varieties into two groups according to their genetic geographical origin and the pedigree.
\end{abstract}

Keywords: genotypes, molecular markers, Prunus avium, RAPD.

\section{INTRODUCTION}

Sweet cherry (Prunus avium L., Rosaceae) is a self-incompatible diploid species, from Rosaceae family, with a number of chromosomes $2 n=16$. Originated around the Caspian and Black Sea, it is cultivate in temperate regions of the world for its edible fruits (Wunsch and Hormaza, 2002).

In Romania, old assortment of cherry was continuously improved with the introduction in the culture of foreign and domestic valuable varieties, but also by the selection of clones of existing range.

The main criterion to assess the genetic diversity of fruit varieties is based on phenotypic and morphological analysis of traits. In most of cases it is often difficult or even impossible to distinguish between many cultivars because they are so morphologically similar (Anna Lisek et al., 2006). Despite its limitations, elaborate and timeconsuming, this method has been used for long time to identify genotypes and to design breeding schemes (Di Vaio et al., 2015).

In the world it is possible to find more than 1.500 cultivars of sweet cherry, so it is very possible to find some cultivars highly similar, or to find the same cultivars with different name, or different cultivars with the same name. As a result, the confusion of the cultivars is an important problem (Özbek, 1978; Kaçar, 2001). In China, for example, exists a problem of homonyms and synonyms in the sweet cherry cultivars (Cai et al., 2007).

At Fruit Research \& Development Station Bistriţa as in all Fruit Development Research Stations from Romania, a large number of Romanian 
and foreign genotypes of sweet cherry (varieties, landrace cultivars, selection and hybrids), have only morphological and biochemical evaluation, less a molecular evaluation. All this characteristics frequently depending by the environmental factors. Molecular analysis are not affected by this factors and can detect differences between cultivars on the genomic level. The counterpart of phenotyping is genotyping (Di Vaio et al., 2015).

Marker-assisted selection would be especially advantageous for sweet and sour cherry, respectively, breeding (Stockinger, 1996). As we know, in the breeding program for any plants, the most important technique is genetic variability. PCR analysis based on RAPD markers has been used for identification and determining relationship in many species, including Prunus. RAPD primers was used to distinguish mutant cherries and their parents (Yang and Schmitt, 1994). To identify 18 sweet cherry cultivars, Gerlach and Stösser (1998) have used twentythree RAPD primers. Anna Lisek et al. (2006) have used 55 RAPD primers to elaborate a simple and reliable procedure for distinguishing among the sweet cherry cultivars commonly cultivated in Poland. Cai et al. (2007) find the specific RAPD markers to study the genetic variation between wild cherry species from a collection held in the Northwest A\&F University (NWAFU). The same markers were used for genotype identification of native Campania sweet cherry cultivars by Vaio., et al. (2015).

The aim of this study was to establish the genetic relationships among the sweet cherry native genotypes belonging to Fruit Research \& Development Station Bistrita, using RAPD markers and to eliminate the possible synonyms between "Van" sweet cherry cultivars from different collection from our country.

\section{MATERIALS AND METHODS}

In present study we analyzed 16 varieties of sweet cherry, of these, a group of 13 representative, native and foreign cultivars (Rosii de Bistrita, Uriase de Bistrita, Timpurii de Bistrita, Negre de Bistrita, Ana, Gloria, Iva, Ivona, Jubileu 30, Rubin, Kordia, Stella andVan, were from collection of the Fruit Research \& Development Station Bistrita, Romania and another three Van cultivars were collected from other three different Stations of Fruit Research from Romania. The cultivars chosen and their geographic and genetic origin are show in Tab. 1.

For PCR analysis, DNA was isolated from young leaves using the protocol described by Lodhi et al., 1994, and modified by Pop et al., 2003. DNA were quantified spectrophotometrically at $260 \mathrm{~nm}$ using a NanoDrop ND 1000 and diluted for a finally concentration of $50 \mathrm{ng} / \mu \mathrm{l}$ in nucleasefree water (Promega).

To distinguish all cherry varieties we used 13 primers RAPD (Operon Technologies Inc., USA). For optimization of PCR conditions and for initial screening were used only four varieties of cherry and only seven primers was selected based on polymorphic bands. The RAPD primers used are presented in Tab. 2.

PCR reactions was performed in a volume of 15 $\mu \mathrm{l}$, with the following component: $50 \mathrm{ng}$ template DNA, 2xPCR master-mix (ready to use, Bioline), $0.2 \mu \mathrm{M} /$ primer and free water. Amplification was carried out in a 96 Well Gradient Palm-Cycler CG196 (Corbett Research), with the following program: initial denaturation step of $94^{\circ} \mathrm{C}$ for $3 \mathrm{~min}$. follow by 45 cycles of $1 \mathrm{~min}$ at $93^{\circ} \mathrm{C}, 1 \mathrm{~min}$. at $34^{\circ} \mathrm{C}$ and $1 \mathrm{~min}$. at $72^{\circ} \mathrm{C}$. The program was completed with the finally extension at $72^{\circ} \mathrm{C}$ for $10 \mathrm{~min}$. After amplification the PCR product was stored at $4^{\circ} \mathrm{C}$ prior to electrophoresis. Amplified DNA fragment were separated in $1 \%$ agarose gel with TAE buffer $1 \%$, stained with etidium bromide. Gels were run for $1,5 \mathrm{~h}$ at $80 \mathrm{~V}$ and visualized under UV light (UVP BioImaging Systems). Each product was visualized on gel with $100 \mathrm{bp}$ DNA Step Ladder molecular marker (Promega) to calculate the bands sizes.

The electrophoresis patterns were analyzed using TotaLab 120. For data matrix, bands were scored as present (1) or absent (0). Genetic distance between varieties was calculated using Jaccard (1908) coefficient of similarity. Cluster analysis was obtained using the PAST software and a dendrogram was generated based on genetic distance.

\section{RESULTS AND DISCUSSION}

The quantity of DNA yield obtained from sweet cherry cultivars was between $196.84-789.75 \mathrm{ng} /$ $\mu \mathrm{l}$ with purity between $2.15-2.21 \mathrm{~nm}$.

Out of 13 primers used for amplification, only seven (54\%) generated a polymorphic band, which was used for genotyping of cherry cultivars, and these were OPE14, OPA03, OPA04, OPA11, 
Tab.1. Native and foreign cultivars of sweet cherry used and their origins

\begin{tabular}{lccc}
\hline $\begin{array}{l}\text { Probe } \\
\text { name }\end{array}$ & Cultivar name & Genetic origin & Origin \\
\hline C1 & Rosii de Bistrita & Hybrid (Hedelfinger x Ramon Oliva) & FRDS Bistrita \\
\hline C2 & Uriase de Bistrita & Hybrid (Hedelfinger x Germersdorf) & FRDS Bistrita \\
\hline C3 & Timpuriu de Bistrita & $\begin{array}{c}\text { Hybrid (Bigarreau Donissen x Ramon } \\
\text { Oliva) }\end{array}$ & FRDS Bistrita \\
\hline C4 & Negre de Bistrita & Hybrid (Hedelfinger x Germersdorf) & FRDS Bistrita \\
\hline C5 & Ana & Hybrid (Hedelfinger x Ramon Oliva) & FRDS Bistrita \\
\hline C6 & Gloria & Hybrid (Boambe de Cotnari x Van) & FRDS Bistrita \\
\hline C7 & Iva & Hybrid (Hedelfinger x Ramon Oliva) & FRDS Bistrita \\
\hline C8 & Ivona & Hybrid (Hedelfinger x Van) & FRDS Bistrita \\
\hline C9 & Jubileu 30 & Hybrid (Hedelfinger x Ramon Oliva) & FRDS Bistrita \\
\hline C10 & Rubin & Hybrid (Hedelfinger x Ramon Oliva) & FRDS Bistrita \\
\hline C11 & Kordia & Unknown & Czech Republic/FRDS Bistrita \\
\hline C12 & Stella & Lambert x John Innes Seedling 2420 & Summerland,B.C./ FRDS Bistrita \\
\hline V_BN & Van & Hybrid (Seedling of Empress Eugenie) & Summerland,B.C./ FRDS Bistrita \\
\hline V_IS & Van & Hybrid (Seedling of Empress Eugenie) & Summerland,B.C./ FRDS Iasi \\
\hline V_P-M & Van & Hybrid (Seedling of Empress Eugenie) & $\begin{array}{c}\text { Summerland,B.C./ RIFG Pitesti- } \\
\text { Maracineni }\end{array}$ \\
\hline V_CJ & Van & Hybrid (Seedling of Empress Eugenie) & $\begin{array}{c}\text { Summerland,B.C./ FGRS Cluj- } \\
\text { Napoca }\end{array}$ \\
\hline
\end{tabular}

FRDS: Fruit Research \& Development Station; FGRS: Fruit Growing Research Station; B.C: British Columbia

Tab. 2. The RAPD primers used in this study, their sequence, the number of bands from which polymorphic and the molecular weight of the bands

\begin{tabular}{lcccccc}
\hline No. & Primer name & Sequence 5'- 3' & $\begin{array}{c}\text { Polymorphic/ } \\
\text { Monomorphic }\end{array}$ & $\begin{array}{c}\text { Bands } \\
\text { (no.) }\end{array}$ & $\begin{array}{c}\text { Polymorphic } \\
\text { bands (no/\%) }\end{array}$ & $\begin{array}{c}\text { Molecular weight } \\
\text { of bands (pb) }\end{array}$ \\
\hline 1 & OPAB 11 & GTGCGCAATG & Monomorphic & - & - & - \\
\hline 2 & OPB 17 & AGGGAACGAG & Monomorphic & - & - & - \\
\hline 3 & OPB 11 & GTAGACCCGT & Monomorphic & - & - & - \\
\hline 4 & OPA 04 & AATCGGGCTG & Polymorphic & 9 & $6(67 \%)$ & $324-1326$ \\
\hline 5 & OPA 11 & CAATCGCCGT & Polymorphic & 10 & $10(100 \%)$ & $862-2152$ \\
\hline 6 & OPB 10 & CTGCTGGGAC & Polymorphic & 11 & $11(100 \%)$ & $1043-2513$ \\
\hline 7 & OPX 03 & TGGCGCAGTG & Monomorphic & - & - & - \\
\hline 8 & AB 11 & CAATCGCCGT & Polymorphic & 10 & $7(70 \%)$ & $403-1270$ \\
\hline 9 & OPB 09 & TGGGGGACTC & Monomorphic & - & - & - \\
\hline 10 & OPX 03 & TGGCGCAGTG & Polymorphic & 11 & $7(64 \%)$ & $175-1160$ \\
\hline 11 & OPB 08 & GTCCACACGG & Monomorphic & - & - & - \\
\hline 12 & OPA 03 & AGTCAGCCAC & Polymorphic & 12 & $11(92 \%)$ & $508-1267$ \\
\hline 13 & OPE 14 & TGCGGCTGAG & Polymorphic & 10 & $8(80 \%)$ & $337-1320$ \\
\hline
\end{tabular}

OPB10, OPX03 and AB11, the rest of primers were monomorphics. The total number of bands obtained with seven selected primers was 73 , the average number of bands per primer was 10.4. Among the 73 fragments, $61(83.56 \%)$ were polymorphics with the average bands per primer 


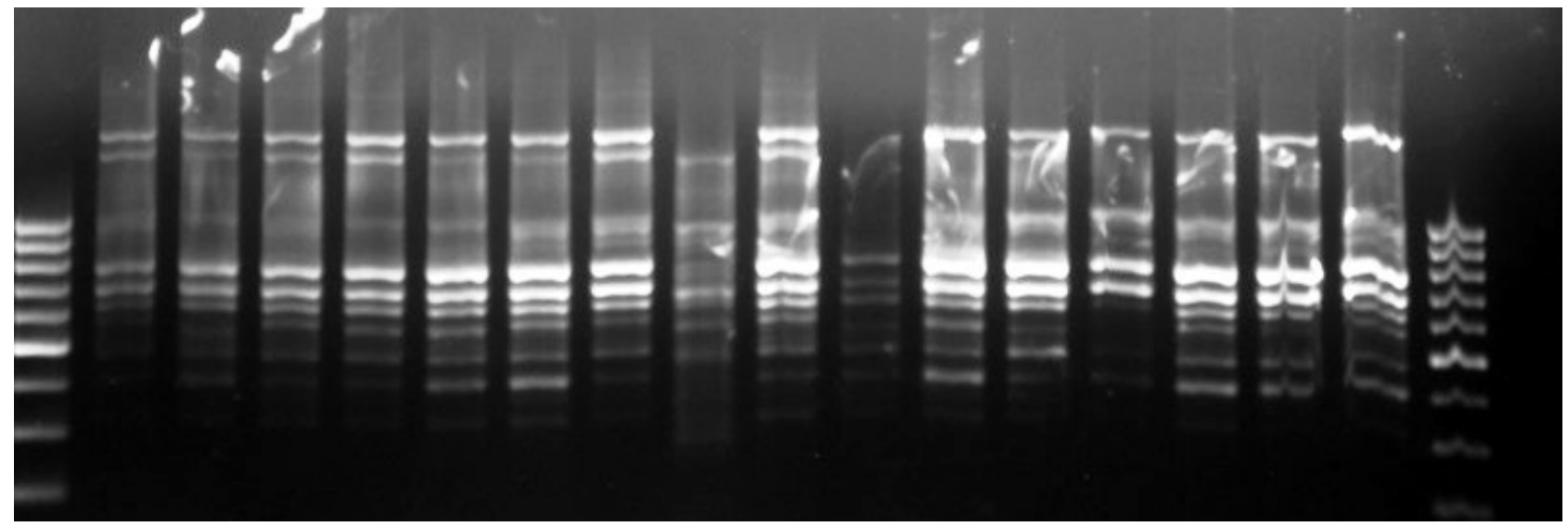

Fig.1. RAPD amplification profile obtained using OPB10 primers (see the probe name in tab.1); Mmolecular marker (100 bp DNA Step Ladder)

of 8.7. The remaining $12(16.4 \%)$ corresponded to monomorphic loci. This number of monomorphic bands confirms the common genetic origin of the most analyzed varieties of cherry.

The molecular weight of the bands ranged from $175 \mathrm{pb}$ to $2513 \mathrm{pb}$. The most polymorphic primer was OPB10 which generated 11 bands from which $100 \%$ were polymorphics, while the primer OPA04 generated only 9 bands from which $67 \%$ were polymorphics (Tab. 2). The primer OPB 10 were previously reported to distinguish the following cultivars "Kordia" and "Vanda", "Summit' and 'Star" (Anna Lisek et al., 2006) and yielded consistent and reproducible polymorphism between accessions (Mayol and Rosselló, 2001). The OPB 10 electrophoresis pattern of this primer is represented in Fig. 1.

With a set of seven RAPD primers it was possible to distinguish the cultivars and seems large enough to represent phylogenetic relationship among all 12 varieties of sweet cherry and to observe the similarity between the rests of four Van cultivars. The results from this study are in agreement with earlier studies using RAPDs in sweet cherry (Anna Lisek et al., 2006; Leyla Demirsoy et al., 2008; Vaio et al., 2015;), and other plant species, like, Juglans cultivars, Rosa cultivar or walnut cultivars (Pop Iulia Francesca et al., 2010; 2011; 2013), or Attalea speciosa (Santos et al., 2015), even in Pseudomonas strains (Jaipreet et al., 2015).

Using Jaccard coefficient was generated a similarity matrix for all polymorphic primers. The dendrogram constructed by PAST software is represented in fig.2. According to the dendrogram results produced by cluster analysis, varieties are separated in two main groups with a similarity value of 0.96 showing a good fit. RAPD primers clustered the varieties according to their geographical origin and almost to their pedigree.

Within the Romanian origin group, all the varieties created at Fruit Research \& Development Station Bistrita were clustered together in a group 1 (Rosii de Bistrita, Uriase de Bistrita, Timpuriu de Bistrita, Negre de Bistrita, Ana, Gloria, Iva, and Ivona). In the second group we found the foreign cultivars, all four Van cultivars, Stella cultivar which is Nord American origin, more exactly from Summerland B.C. (Lapins, 1971) and Kordia cultivar which is European origin (Czech Republic) but with unknown genetic origin (http://treefruit. wsu.edu/variety/attika-kordia). The fact that all four Van varieties are grouped together eliminate the problem of the existence of possible the synonyms in the Romanian national collections.

If regarding more exactly in group 1 , all the cultivars were grouped together because they have at least one of the parents common. Here can be observed a subgroup includes 'Rosii de Bistrita` and 'Timpuriu de Bistrita' which have the highest similarity value between them (0.87). One of the parents of them is Ramon Oliva cultivar.

A high value of similarity is found between 'Rosii de Bistrita' and 'Uriase de Bistrita' (0.84) and common genitor of them is variety of German origin - Hedelfinger. The same variety Hedelfinger is found as one of genetic genitor for 'Negre de Bistrita', 'Ana', 'Ivona, 'Jubileu 30` and 'Rubin`. 


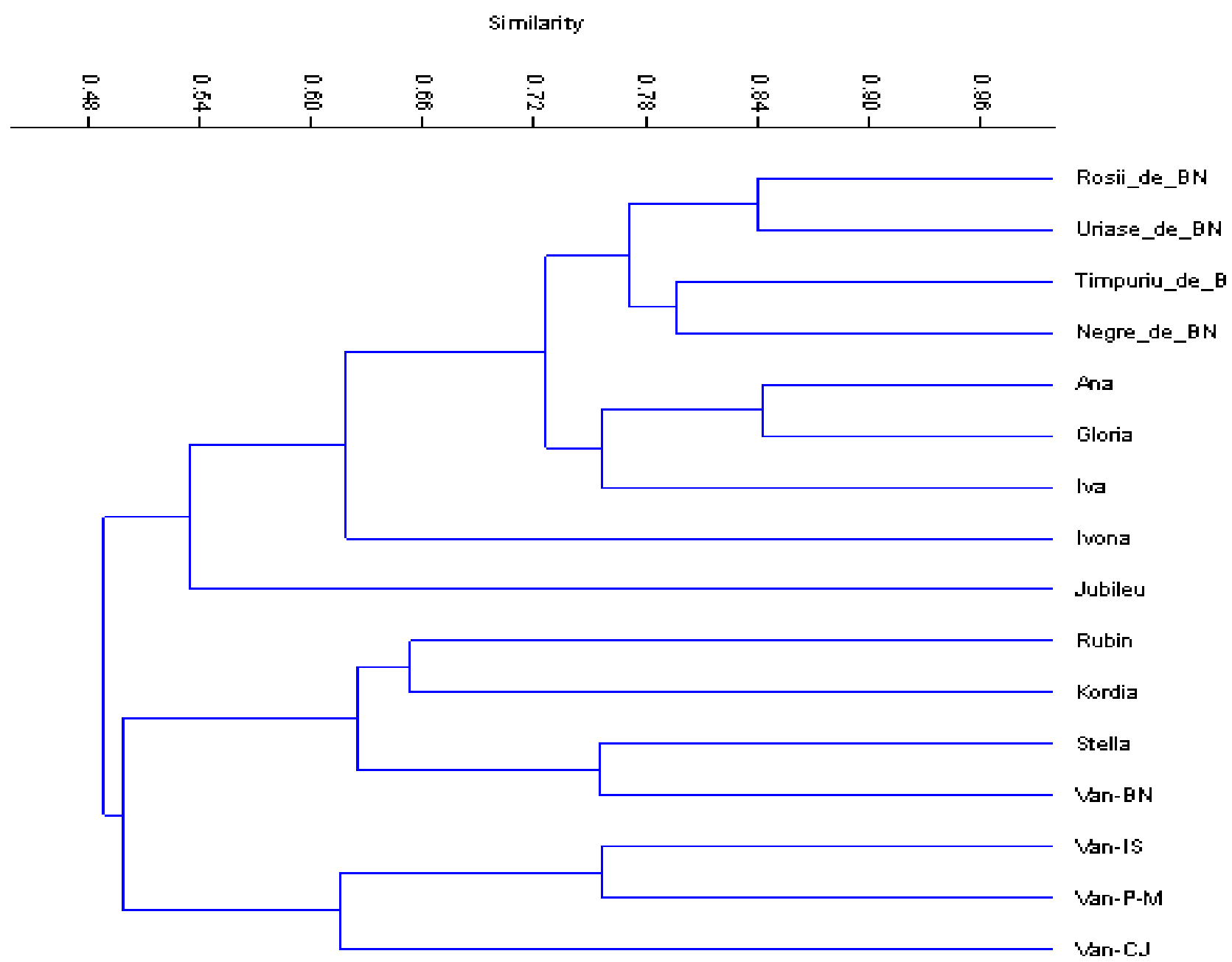

Fig. 2. Dendrogram generated using PAST software, based on the genetic relationships between sweet cherry varieties and the similarity calculated using Jaccard coefficient

'Iva' cultivar, which have the same genetic origin (Hedelfingen x Ramon Oliva) is near 'Ana' and 'Gloria`. The similarity value between them is 0.80 ('Iva`and 'Gloria') and 0.72 ('Iva`and `Ana'). 'Ivona' cultivar, as shown in dendrogram is at the limit between the groups, because of the second parent - Van, the similarity value between them is 0.56 . But the highest value of similarity is between 'Ivona' and 'Iva' (0.70). That confirms the one of the common parent of these cultivars which is Hedelfingen variety.

Subgroup 'Rubin' and 'Kordia' grouped together in the second group. The similarity value between them is 0.65 . A question mark the presence of 'Rubin` cultivar in this group because it is a native from Fruit Research \& Development Station Bistrita, obtained from crossing between
Hedelfinger x Ramon Oliva. But 'Kordia` cultivar with the unknown genetic origin, all we know is his geographical origin, Czech Republic. They have some similar agronomical characteristically, like medium vigor of the tree, high productivity, "Kordia, produced high and very large fruits, with good quality (Kazantzis et al., 2011), late ripening varieties of both (June $25^{\text {th }}-$ July $5^{\text {th }}$ for Kordia and the last decade of June for Rubin). Also, in Australia, 'Kordia' cultivar is widely grown for good fruits size, flavor and quality (Bound et al., 2014).

\section{CONCLUSION}

The RAPD primers used in analysis could identify the relationship between cultivars from FRDS Bistrita, based on their genetic origin. 
But to explain in detail some other aspects is recommended to repeat the analysis using more RAPD primers or extend the molecular analysis with another technique which offers an "image" more exactly on this situation.

Acknowledgments. I would like to thank Senior Scientist I, PhD Ioan Zagrai from Fruit Research \& Development Station Bistrita, for genetic material and for details about the origin of varieties.

\section{REFERENCES}

1. Bound SA, Close DC, and Jone JE (2014). Improving Fruit Set of 'Kordia' and 'Regina' Sweet Cherry with AVG Acta horticulturae 1042:285-292

2. Cai YL, Gui-Fang Z, Dong-Wei C (2005). Studies on genetic variation in wild cherry using RAPD analysis. Scientia Horticulturae, 111: 248-254

3. Di Vaio C, Villano C and Marallo N (2015). Molecular analysis of native cultivars of sweet cherry in Southern Italy. Hort. Sci. (Prague), Vol. 42,(3): 114-118

4. Gerlach, Stösser (1998). Sweet cherry cultivar identification using RAPD derived DNA fingerprints, Acta Hortic. 468: 63-70

5. Ghidra V, Botu M, Sestraș R, Botu I (2004). Biodiversitate şi Bioconservare, Cluj Napoca, Editura Academic Pres.

6. Jaccard P (1908). Nouvelles recherches sur la distribution florale, Bull. Soc. Vaud. Sci. Nat., 44: 223-270

7. Rayar JK, Arif M, and Uma Singh S, (2015). Relative efficiency of RAPD and ISSR markers in assessment of DNA polymorphism and genetic diversity among Pseudomonas strains. Afr. J. Biotechnol., 14(13): 1097-1106.

8. Kaçar YA, (2001). Classification of important sweet cherry (Prunus avium L.) and sour cherry (Prunus cerasus L.) cultivars and types growing in turkey by DNA fingerprinting methods, Cukurova Univ., Docthoral thesis, Adana, Turkey, $190 \mathrm{p}$.

9. Kazantzis K, Chatzicharissis I, Papachatzis A, Sotiropoulos T, Kalorizou H and Koutinas N (2011). Evaluation of sweet cherry cultivars introduced in Greece. University of Craiova Vol. XVI (LII): 293-296

10. Lapins KO (1971). Stella, a self-fruitful sweet cherry. Can J. Plant Sci. 5l:252-253.

11. Lisek A, Korbin M, and Rozpara E (2006). Using simply generated RAPD markers to distinguish between sweet cherry (Prunus avium l.) cultivars. J. Fruit Ornam. Plant Res., 14 (Suppl. 1): 53-59.
12. Lodhi, MA, Guang-Ning Z, Weedenreisch FNF, and Reisch BI (1994). A simple and efficient method for DNA extraction from grapevine cultivars, vitis species and ampelopsis. Plant Molecular Biology Reporter 12(1):6-13.

13. Mayol M, and Rosselló JA (2001). RAPD differentiation between Borderea pyrenaica and B. chouardii (Dioscoreaceae), two relict endangered taxa. Israel Journal of Plant Sciences, 49: 259-268

14. Özbek S, (1978). Special fruit growing, Ankara Univ. Press., Ankara, Turkey, 128 (11): 485.

15. Pop IF, Vicol AC, Botu M, Raica PA, Vahdati K, Pamfil D (2013). Relationships of walnut cultivars in a germplasm collection: Comparative analysis of phenotypic and molecular data. Scientia Horticulturae 153 (2013): 124135

16. Pop IF, Pamfil D, Raica P, Petricele IV, Sisea C, Vas E, Botos B, Bodea M, and Botu M (2010). Assessment of the genetic variability among some Juglans cultivars from the Romanian National Collection at S.C.D. P. Valcea using RAPD markers. Romanian Biotechnological Letters, 15 (2), Supplement: 41-49

17. Pop IF, Monica Harta, Stefan Wagner and Doru Pamfil (2011). Molecular characterization of Romanian rose genotypes based on RAPD markers. Bulletin UASVM Horticulture, 68(1):55-59

18. Pop R., Ardelean M, Pamfil D, and Gaboreanu IM (2003), The efficiency of different DNA isolation and purification in ten cultivars of Vitis vinifera., Bul. USAMV (ZB) 59:259261.

19. Santos MF, Damasceno-Silva KJ, Carvalhaes MA and Lima PSC (2015). Genetic variation detected by RAPD markers in natural populations of babassu palm (Attalea speciosa Mart.). Genet. Mol. Res. 14 (2): 6124-6135.

20. Stockinger EJ, Mulinix CA, Long CM, Brettin TS, and Lezzoni AF (1996). A linkage map of sweet cherry based on RAPD analysis of a microspore-derived callus culture population. Journal of Heredity 87:214-218.

21. Wunsch A and Hormaza JI (2002). Molecular characterisation of sweet cherry (Prunus avium L.) genotypes using peach [Prunus persica (L.) Batsch] SSR sequences. Heredity 89:56-63.

22. Yang, H. and Schmitt, H. (1994). Selection of a mutant from adventitious shoots formed in X-ray treated leaves and differentiation of standard from mutant with RAPDs. Euphytica 93:129-143.

23. ***, http://treefruit.wsu.edu/variety/attika-kordia 